\author{
dr Piotr PIETRZAK \\ Wydział Nauk Ekonomicznych, Szkoła Główna Gospodarstwa Wiejskiego w Warszawie \\ e-mail: piotr_pietrzak1@sggw.pl \\ dr hab. Michał PIETRZAK, prof. SGGW \\ Wydział Nauk Ekonomicznych, Szkoła Główna Gospodarstwa Wiejskiego w Warszawie \\ e-mail: michal_pietrzak@sggw.pl
}

DOI: $10.15290 /$ oes.2018.01.91.07

\title{
ZASTOSOWANIE METOD ZARZĄDZANIA STRATEGICZNEGO W SEKTORZE PUBLICZNYM - MAPA GRUP STRATEGICZNYCH WYDZIALÓW NAUK SPOŁECZNYCH
}

\begin{abstract}
Streszczenie
W artykule podjęto dyskusję na temat możliwości wykorzystania mapy grup strategicznych w sektorze publicznego szkolnictwa wyższego. Ponadto przeprowadzono weryfikację empiryczna - tworząc mapę grup strategicznych opartą na danych pochodzących z 33 wydziałów reprezentujących nauki społeczne. W publikacji autorzy wykorzystali podejście zaproponowane przez Warning, zgodnie z którym szkoły wyższe dążą do strategicznego kompromisu między działalnością dydaktyczną a naukowa (przy czym w tekście dokonano dodatkowo rozróżnienia na działalność naukowa „teoretyczną” i „praktyczną"). Grupowanie wydziałów przeprowadzono opierając na metodzie Warda, stosując odległość euklidesowa. Przeprowadzona procedura pozwoliła na wyodrębnienie sześciu grup strategicznych. Ponadto zweryfikowano hipotezę o związku między efektywnością funkcjonowania wydziałów a wyrazistością ich strategii. Proporcjonalnie najwięcej efektywnych wydziałów należy do kategorii jednostek z wyrazistą strategią nastawioną na rozwój naukowy „teoretyczny” lub „praktyczny”.
\end{abstract}

Słowa kluczowe: sektor publiczny, szkoły wyższe, zarządzanie strategiczne, mapa grup strategicznych, efektywność

\section{APPLICATION OF STRATEGIC MANAGEMENT METHODS IN THE PUBLIC SECTOR - THE MAP OF STRATEGIC GROUPS OF FACULTIES OF SOCIAL SCIENCES}

\begin{abstract}
Summary
The paper discusses the potential for using the map of strategic groups in the public higher education sector. In addition, empirical verification was performed - by drawing a map of strategic groups based on data from 33 faculties which represent the social sciences. In this article, the authors have used the approach proposed by Warning, whereby higher education institutions strive for a strategic compromise between teaching and research (additionally we divided research into "theoretical" and "practical" activities). Grouping of faculties was done basing on the Ward method and using the Euclidean distance. The procedure allowed us to distinguish six strategic groups. In addition, the authors hypothesize the correlation between the efficiency of faculty performance and their strategic choices.
\end{abstract}


One could find that the most efficient faculties are those which are different from "stuck-inthe-middle" faculties, namely those with distinctive emphasis on "theoretical" or "practical" research.

Key words: public sector, Higher Education Institutions, strategic management, map of strategic groups, efficiency

\section{Wstęp}

Edukacja wyższa wymyka się prostemu rozróżnieniu dóbr prywatnych i dóbr publicznych [Pietrzak, 2016, s. 36-39]. Ma ona charakter dobra mieszanego (publiczno-prywatnego) określanego jako dobro merytoryczne [Musgrave, 1987, s. 452-453]. W efekcie szkolnictwo wyższe finansowane jest zarówno ze środków publicznych, jak i prywatnych, przy czym proporcje te różnią się znacznie w różnych krajach, jednakże w Europie zdecydowanie przeważa finansowanie ze środków publicznych [Paliszkiewicz, 2010, s. 172-173].

Obecnie można zaobserwować, że publiczne szkoły wyższe coraz częściej sięgaja po metody i techniki rozwinięte na użytek biznesu [Parker 2012, s. 250]. Poczesne miejsce zajmują wśród nich metody i techniki z zakresu zarządzania strategicznego. Jest to przejawem coraz szerszej aplikacji koncepcji New Public Management (NPM) w szkolnictwie wyższym, szczególnie w Europie [Schimank, 2005, s. 362, Tahar, 2013, s. 687; Wilkesmann i Schmid, 2012, s. 34]. Nowe Zarządzanie Publiczne wyrosłe na gruncie ekonomii (teorii wyboru publicznego, teorii kosztów transakcyjnych, teorii agencji, teorii praw własności, szkoły austriackiej) oraz teorii zarządzania [Hood, 1991, s. 5; Zawicki, 2011, s. 36] zaoferowało teoretyczne podstawy do krytyki tradycyjnego administrowania w sektorze publicznym bazującego na modelu idealnej biurokracji Webera [O'Flynn, 2007, s. 354]. Trafna w tym względzie jest opinia Hughesa, że: ,administrowanie oznacza wypełnianie intrukcji, natomiast zarządzanie to osiaganie rezultatów” [cyt. za: Zawicki, 2011, s. 39]. Aplikacja NPM w szkolnictwie wyższym towarzyszy obserwowanej ewolucji uniwersytetu liberalnego (humboldtowskiego) w kierunku uniwersytetu przedsiębiorczego opisanej szerzej przez Leję [2013, s. 29-75] oraz Sułkowskiego [2016, s. 13-24].

Część autorów krytycznie odnosi się do wspomnianej transformacji uniwersytetu. Sztompka broni humboldtowskiej koncepcji uniwersytetu jako instytucji niezbędnej dla prawidłowego rozwoju demokracji i kapitalizmu [2016, s. 54-58]. „Zostawiliśmy edukację obywatelską demagogom i tabloidom (...). A edukację cywilizacyjną zostawiliśmy ulicy, galeriom handlowym, serialom telewizyjnym i Internetowi. $\mathrm{Na}$ najlepiej nawet wyspecjalizowanej sile roboczej nie zbudujemy przyszłości Polski” [Sztompka, 2016, s. 58]. Syntetyczny przegląd obaw związanych z przemianami w szkolnictwie wyższym przedstawiła Kostera [2013, s. 11-17]. Zwraca jednak ona uwagę na specyfikę naszej epoki - baumanowskie interregnum tj. okres wyczerpywania się starych instytucji, podczas, gdy nowe jeszcze się nie wykrystalizowały. Współcześnie presja na legitymizacje wszystkiego przez pragmatycznie rozumiana użyteczność utrudnia przedstawianie wiedzy i cnót obywatelskich jako wartości autotelicznych [por. Kostera, 2013 s. 11-12]. Nie jest zamiarem autorów próba 
rozstrzygania w tym miejscu zarysowanych kontrowersji. Niemniej faktem jest, że transformacja $\mathrm{w}$ kierunku uniwersytetu przedsiębiorczego ma miejsce $\mathrm{i} w$ dużej mierze wynika z przesłanek obiektywnych ${ }^{1}$. W konsekwencji tej transformacji uniwersytety coraz częściej czerpią z metod i narzędzi zarządzania w biznesie, w tym również - zarządzania strategicznego.

Celem niniejszego artykułu jest weryfikacja potencjału mapy grup strategicznych jako narzędzia zarządzania w publicznym szkolnictwie wyższym. Dążąc do realizacji tego celu autorzy dokonali przeglądu literatury w zakresie koncepcji struktury sektora i grup strategicznych w szczególności oraz w zakresie wizualizacji mapy grup strategicznych oraz jej wykorzystania w procesie zarządzania. Następnie przeprowadzono weryfikacje empiryczną - tworząc mapę grup strategicznych w oparciu o dane pochodzące z 33 wydziałów reprezentujące nauki społeczne (tj. dziennikarstwo, ekonomia, zarządzanie, prawo, psychologia, socjologia $i$ inne) oraz sprawdzając ewentualny związek przynależności do różnych grup z efektywnością.

\section{Przegląd literatury}

Zarządzanie strategiczne można określić jako „dyscyplinę pogranicza”, która rozwinęła się na styku teorii zarządzania i teorii ekonomii, w szczególności dzięki konwergencji Business Policy („Polityki firmy”2) oraz Industrial Organization (ekonomii branży $)^{3}$.

Podstawowym podejściem badawczym ekonomii branży jest paradygmat S-C-P (Structure-Conduct-Performance), określany jako koncepcja Baina/Masona lub jako „szkoła harwardzka” [Matyjas, 2011, s. 313; Tirole, 1988, s. 1]. Według tego paradygmatu Structure tj. struktura sektora determinuje Conduct tj. zachowania/ strategie przedsiębiorstw, a w konsekwencji Performance tj. wyniki/efektywność sektora [Scherer, 1970, s. 4-5, 8-11; Carlotn, Perloff, 2005, s. 2-4]. W przeciwieństwie do mało naukowego, jakościowego podejścia do analizy otoczenia stosowanego w literaturze z zakresu Business Policy, Industrial Organization zaoferowała usystematyzowany model do oceny natury konkurencji w branży - oparty na empirycznie weryfikowanych podstawach naukowych [Porter, 1981, s. 611].

Za najbardziej wpływowy wkład ekonomii w rozwój zarządzania strategicznego w dekadzie 1980-1990 została uznana książka Portera Strategia konkurengi [Rumelt,

1 Sułkowski [2016, s. 17] wymienia tu: problemy z finansowaniem ze środków publicznych, konkurencja ze strony alternatywnych instytucji edukacyjnych, umasowienie studiów wyższych, biurokratyzację uniwersytetów i komercjalizację nauki.

2 Przedmiot nauczany w amerykańskich szkołach biznesu od 1912 roku, którego zadaniem była integracja wiedzy pozyskanej z wielu wyspecjalizowanych funkcjonalnie obszarów działania przedsiębiorstwa w celu kompleksowego spojrzenia z punktu widzenia dyrektora generalnego na całość problemów biznesowych decydujących o porażce bądź sukcesie firmy [Ghemawat, 1999, s. 5; Rumelt, Schendel, Teece, 1991, s. 6-7; Schendel, Hatten, 1972, s. 99].

3 Termin zaproponowany jako tłumaczenie stosowanych w literaturze anglojęzycznej Industrial Organization lub Industrial Economics przez M.Gorynię, B. Jaworska, R. Owczarzaka, s. 606. 
Schendel, Teece, 1991, s. 8], która - w pewnym uproszczeniu - można uznać za zakotwiczone w Industrial Organization ,ttumaczenie" modelu S-C-P z uwzględnieniem najnowszych osiagnięć ekonomii branży [por. Foss, 1996, s. 11-12]. Książka ta spopularyzowała koncepcję grup strategicznych.

Paradygmat S-C-P zakładał, że różnice pomiędzy strukturami sektorów powinny wyjaśniać różnice w efektywności, w tym - rentowności. Założenie to było weryfikowane $\mathrm{w}$ setkach badań empirycznych. Najbardziej prominentne spośród tych badań - przeprowadzone na olbrzymich próbach badawczych przez Schmalensee (1985), Rumelta (1991) oraz McGahan i Portera (1997) wskazuja na wpływ struktury na rentowność na poziomie odpowiednio: $19,46 \%, 8,28 \%$ oraz 18,68\% wyjaśnionej wariancji. Niezależnie od różnic w uzyskanych wynikach, badania te wskazuja na wpływ sektora na rentowność, ale „podczas gdy różnice między sektorami maja znaczenie, to jednak oczywiście nie są wszystkim co ma znaczenie” [Schmalensee, 1985, s. 350]. Ważnym problemem badawczym jest w związku z tym zrozumienie nie tylko istoty różnic międzysektorowych (które próbuje wyjaśnić paradygmat S-C-P), ale także zrozumienie różnic wewnątrzsektorowych. Jednym z możliwych wyjaśnień tych różnic jest właśnie koncepcja grup strategicznych, która wiąże się $\mathrm{z}$ badaniami prowadzonymi na wydziale ekonomicznym Harvarda, gdzie uczniowie Richarda Cavesa (Hunt, Newman i Porter) modyfikowali tradycyjny paradygmat S-C-P tak, aby uwzględnić zróżnicowanie pozycji firm wewnątrz sektora [Rumelt, Schendel, Teece, 1991, s. 8].

Pierwszy raz pojęcie ,grupy strategiczne” zostało wykorzystane przez Hunta w jego rozprawie doktorskiej z 1972 roku [McGee, Thomas, 1986, s. 142]. Rozważania nad grupami strategicznymi kontynuował Newman argumentując, że firmy konkurując na tym samym rynku, kierując się tym samym celem maksymalizacji zysku - nie muszą stosować takich samych strategii, zaś jeśli strategie firm mogą się trwale różnić - można mówić o grupach strategicznych (obejmujących firmy o wysokim stopniu symetryczności strategii), jako o stałym elemencie struktury rynku [1978, s. 417-419]. Kolejny uczeń Cavesa - Porter jest również autorem najczęściej cytowanej definicji grup strategicznych: „Grupa strategiczna jest to taka grupa firm w sektorze, która stosuje taką samą lub podobną strategię według wymiarów strategicznych" [Porter, 1998 s. 140].

Równolegle z omówionymi wyżej badaniami prowadzonymi przez szkołę harwardzką, na Uniwesytecie Purdue Dan Schendel i Arnold Cooper wraz ze swoimi studentami rozpoczynają studia nad sektorem browarniczym. Interpretując strategię w kategoriach różnic w zasobach analizuja jej związek z efektywnością i udowadniaja istnienie zróżnicowania wewnątrz sektora $\mathrm{w}$ formie grup strategicznych [Rumelt $\mathrm{i}$ in. 1991, s. 8]. Nastapiło znaczące rozszerzenie zainteresowania koncepcja grup strategicznych, która szybko została zaadaptowana przez rodzącą się w latach 70. ubiegłego wieku nową dyscyplinę: zarządzanie strategiczne.

$\mathrm{Na}$ gruncie zarządzania strategicznego narodziła się idea wizualizacji zróżnicowania struktury wewnętrznej sektora w postaci map grup strategicznych tj. wykresu opartego na dwóch najważniejszych wymiarach strategicznych (lub agregatach istotnych zmiennych strategicznych), przy czym grupy strategiczne sa prezentowane 
w takiej dwuwymiarowej przestrzeni pod symbolami kół o powierzchni proporcjonalnej do znaczenia danej grupy w sektorze [Porter 1998, s. 141].

Mapa grup strategicznych jest użytecznym narzędziem, które pomaga w poszukiwaniu odpowiedzi na istotne problemy: jak działa konkurencja w sektorze? Jakie sa konsekwencje różnych zachowań strategicznych? Jaka będzie dynamika sytuacji konkurencyjnej w sektorze? Jak się będa zmieniać konkurenci? [Pruett i Thomas, 1994, s. vii]. Często odpowiedzi tych szuka się na poziomie całego sektora (np. paradygmat S-C-P lub model 5 sił według Portera) albo na poziomie pojedynczych organizacji. Mapa grup strategicznych jest swego rodzaju „mostem” pomiędzy spojrzeniem na sektor jako na monolityczną całość i spojrzeniem na odrębne, indywidualne podmioty sektora [Thompson, Strickland, 1990, s. 78].

Grupy strategiczne jako przedmiot badań doczekały się licznych studiów empirycznych obejmujących rozmaite branże gospodarki. Jednakże baza takich badań w odniesieniu do szkolnictwa wyższego jest bardzo skromna ${ }^{4}$ [Adam, 2016; Martinez i Wolverton, 2009; Pietrzak i Pietrzak, 2017; Warning, 2004, 2007; Wójcik-Augustyniak, 2011]. Tak więc wydaje się, że podjęcie próby opracowania mapy grup strategicznych w sektorze publicznego szkolnictwa wyższego w Polsce jest w pełni uzasadnione.

\section{Materiał i metody}

Większość dotychczasowych badań dotyczących grup strategicznych w szkolnictwie wyższym przyjmuje uniwersytet jako jednostkę analityczna. Tymczasem, uniwersytet składa się z wielu wydziałów. Występuje tu zatem analogia do biznesu, gdzie duże korporacje składają się typowo $\mathrm{z}$ wielu względnie niezależnych dywizji (oddziałów), traktowanych w procesie zarządzania strategicznego jako strategiczne jednostki biznesu (SJB). Zazwyczaj duże korporacje działają równocześnie w wielu sektorach - jak zatem miałaby wyglądać mapa grup strategicznych (która dotyczy konkretnego sektora) dla korporacji? W literaturze podkreśla się rozróżnienie między strategia na poziomie korporacji i strategia na poziomie SJB [De Witt \& Meyer 2007, s. 145]. W istocie mapa grup strategicznych wspiera opracowanie strategii dla konkretnej jednostki biznesowej, dlatego, zdaniem autorów, w grupowaniu strategicznym jednostką analityczną powinien być wydział, a nie uniwersytet jako całość.

Wychodząc z powyższego założenia, badaniem objęto wydziały reprezentujące nauki społeczne (dziennikarstwo, ekonomia, zarządzanie, prawo, socjologia, psychologia). Obecnie w Polsce na uczelniach publicznych funkcjonuje blisko 150 wydziałów tego typu, jednakże jedynie dla 33 dostępne sa porównywalne dane. Statystyki dotyczące liczby nauczycieli akademickich, studentów, publikacji, wartości pozyskanych grantów i prac zleconych (KZL) zostały zaczerpnięte ze „Sprawozdań rekto-

$4 \quad$ Przegląd tych opracowań znajdzie Czytelnik w [Pietrzak i Pietrzak, 2017, s. 4-5]. 
rów z działalności uczelni za rok 2013" udostępnianych w Biuletynach Informacji Publicznej.

W procesie tworzenia mapy grup strategicznych fundamentalne znaczenie posiada wybór dwóch kryteriów różnicujących strategie funkcjonowania podmiotów na rynku [Fudaliński, 2005, s. 57], czyli tzw. wymiarów strategicznych. W artykule autorzy wykorzystali podejście zaproponowane przez Warning, zgodnie z którym podstawową decyzja strategiczną w obrębie szkół wyższych jest wybór między koncentracją na działalności dydaktycznej, a koncentracją na działalności naukowej [Warning, 2004, s. 395]. W praktyce koncentracja na działalności naukowej oznacza intensyfikację aktywności publikacyjnej. Kryteria takie jak: liczba artykułów czy liczba cytowań sa powszechnie wykorzystywane w procesie oceny pracowników, jak i przy paramteryzacji wydziałów. Warto jednak nadmienić, że w polskiej praktyce funkcjonowania uczelni publikacje naukowe posiadaja często charakter teoretyczny i nie poruszają aspektów praktycznych. Panuje powszechne przekonanie, że w Polsce, transfer wiedzy z uczelni do szeroko pojętego otoczenia społeczno-gospodarczego jest na niewystarczającym poziomie. Dlatego autorzy rozróżnili działalność naukową ,teoretyczną" (koncentracja na pisaniu artykułów naukowych) i działalność naukowa "praktyczną" (koncentracja na zaspokajaniu potrzeb otoczenia społeczno-gospodarczego, mierzona wartością pozyskanych środków z grantów i prac zleconych).

A zatem autorzy wyszli od propozycji Warning, ale modyfikując ją - w efekcie kryteriami różnicującymi strategicznie działalność wydziałów reprezentujących nauki społeczne są: relacja między liczbą publikacji a liczbą studentów (koncentracja na „teoretycznej” działalności naukowej versus koncentracja na działalności dydaktycznej) oraz relacja między wartościa grantów i prac zleconych a liczbą studentów (koncentracja na „praktycznej” działalności naukowej versus koncentracja na działalności dydaktycznej).

Operając się na opisanych powyżej kryteriach została przeprowadzona analiza skupień. Z literatury przedmiotu wynika, że najlepsze własności formalne wśród hierarchicznych metod aglomeracyjnych posiada metoda Warda, której efektywność wykrywania prawdziwej struktury danych jest o około $40 \%$ lepsza niż w przypadku metody pojedynczego wiązania [Berbeka, 2006, s. 46]. Metoda Warda do oszacowania odległości między skupieniami wykorzystuje podejście analizy wariancji metoda ta dąży do minimalizacji sumy kwadratów dowolnych dwóch skupień, które mogą zostać uformowane na każdym etapie aglomeracji. Aczkolwiek, należy zauważyć, że metoda Warda zmierza do tworzenia skupień o małej wielkości [Michalski, 2007, s. 12].

Wokół skupisk przedsiębiorstw (tu: wydziałów reprezentujących nauki społeczne) w różnych obszarach mapy zakreśla się koła proporcjonalne do wielkości grupy strategicznej określanej jej udziałem w sprzedaży. W niniejszym artykule wielkość kół odzwierciedla łączną liczbę studentów danej grupy wydziałów (tj. skupienia).

Ponadto autorzy niniejszego artykułu, bazując na teorii grup strategicznych, stawiają hipotezę o związku między efektywnością funkcjonowania wydziałów a ich profilem strategicznym. 
W pomiarze efektywności wydziałów wykorzystano nieparametryczną metodę DEA (Data Envelopment Analysis). Autorzy tej metody (Charnes, Cooper i Rhodes) bazując na koncepcji produktywności sformułowanej przez Debreu i Farella, zastosowali ją do sytuacji wielowymiarowej [Charnes, Cooper, Rhodes 1978, s. 429-444]. Tym samym, metoda DEA umożliwia badanie relacji między poziomem wielu nakładów a wielu efektów.

W celu określenia zależności między efektywnością wydziałów a ich profilem strategicznym autorzy posłużyli się testem niezależności chi kwadrat $\left(\chi^{2}\right)$. Zaś w procesie przetwarzania materiału badawczego wykorzystano arkusz kalkulacyjny Microsoft Excel 2013, program STATISTICA 7.0 oraz DEA Solver Pro.

\section{Wyniki badań}

Celem przeprowadzonej analizy skupień był podział wydziałów reprezentujących nauki społeczne na grupy różniące się profilem strategicznym. Wyodrębnione grupy powinny spełniać kryteria wewnętrznej spójności, czyli homogeniczności oraz zewnętrznej izolacji (heterogeniczności). Na rysunku 1 przedstawiono dendrogram ilustrujący otrzymaną hierarchię skupień. Oś pozioma wskazuje odległość wiązania, w tym przypadku odległość euklidesowa, zaś oś pionowa wydziały reprezentujące nauki społeczne.

RYSUNEK 1.

\section{Aglomeracja metodą Warda}

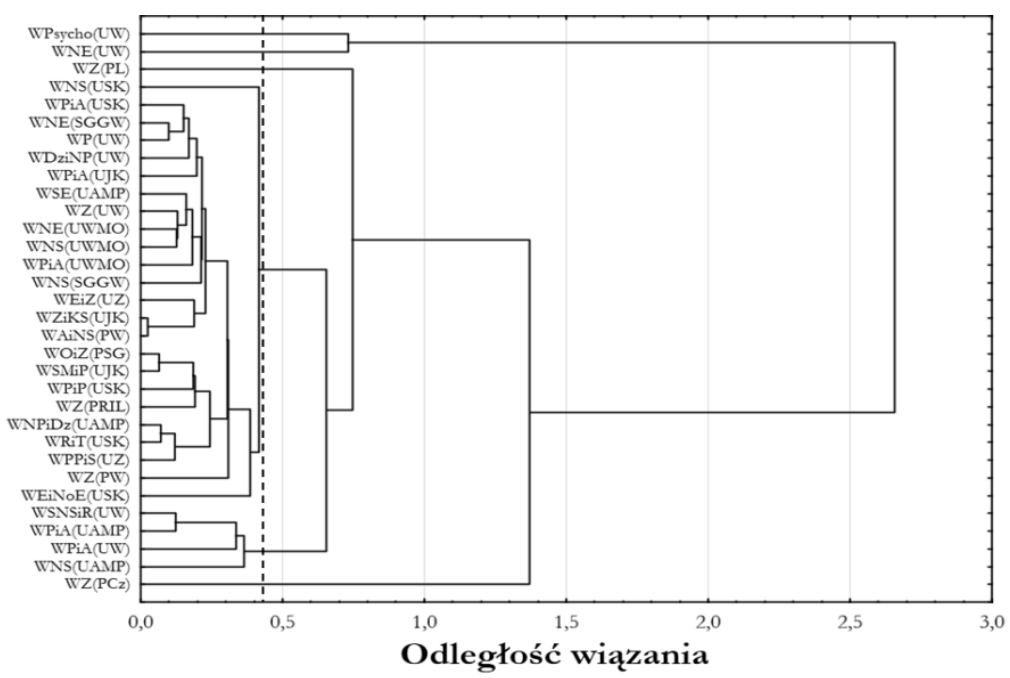

Źródło: opracowanie własne.

Aby określić optymalną liczbę skupień, posłużono się wykresem przebiegu aglomeracji, na którym przedstawiono odległości między skupieniami w momencie ich łączenia - rysunek 2. Punkt odcięcia wyznacza się w miejscu nagłego wzrostu 
odległości wiązania. W analizowanym przypadku znajduje się on między krokiem 26 a 27. Jego rzędna odpowiada odległości między wiązaniami wynoszącej około 0,4. Stąd możliwe było wyodrębnienie sześciu skupień (por. linia przerywana na rysunku 1). Ich charakterystykę zawiera tabela 1.

RYSUNEK 2.

\section{Wykres odległości wiązania względem etapów wiązania}

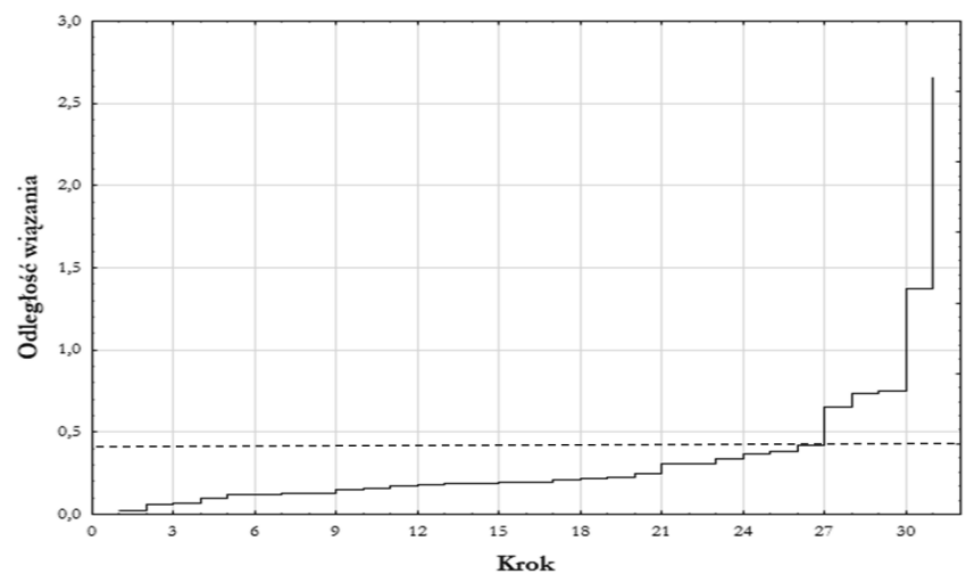

Źródło: opracowanie własne.

Wyniki analizy skupień w postaci mapy grup strategicznych przedstawiono na rysunku 3. Mapa ukazuje jaki jest profil strategiczny poszczególnych grup wydziałów reprezentujących nauki społeczne tzn., które grupy koncentrują się na działalności dydaktycznej, które na „teoretycznej” działalności naukowej, i w końcu, które na „praktycznej” działalności naukowej.

Z rysunku 3. wynika, że grupy A i B, to wydziały wyróżniające się w zakresie „praktycznej” działalności naukowej (mierzonej wartością pozyskanych funduszy na badania w stosunku do liczby studentów). Są to pojedyncze „grupy” tzn. złożone tylko z jednego wydziału - odpowiednio: Wydziału Psychologii UW oraz Wydziału Nauk Ekonomicznych UW. Grupy D, E, F to wydziały, które z kolei, wyróżniają się w zakresie „teoretycznej” działalności naukowej (mierzonej liczbą publikacji w stosunku do liczby studentów). Łącznie w tych trzech grupach znalazło się sześć wydziałów. Grupa C, w skład której weszła największa liczba obiektów (24), to wydziały, które można określić mianem „tradycyjnych”. Osiagają one przeciętne wyniki w zakresie działalności dydaktycznej oraz naukowej - zarówno o charakterze „praktycznym” jak i „teoretycznym”.

W kolejnym kroku analizy określono efektywność wydziałów przy użyciu wskaźnika efektywności DEA oraz podzielono je na: wysokoefektywne (powyżej 66 percentyla), średnioefektywne (powyżej 33 i poniżej 66 percentyla) oraz niskoefektywne (poniżej 33 percentyla). Przydzieloną kategorię efektywności skonfrontowano z profilem strategicznym wydziałów - tabela 2. 
TABELA 1.

Charakterystyka grup strategicznych

\begin{tabular}{|c|c|c|c|}
\hline $\begin{array}{c}\text { Grupa } \\
\text { strategiczna } \\
\text { (liczba studentów } \\
\text { w tys. osób) } \\
\end{array}$ & ID* & $\begin{array}{l}\text { Liczba publikacji } \\
\text { vs. liczba } \\
\text { studentów }\end{array}$ & $\begin{array}{l}\text { Wartość grantów } \\
\text { i prac zleconych } \\
\text { vs. liczba studentów }\end{array}$ \\
\hline $\mathrm{A}(1,4)$ & WPsycho(UW) & 0,09 & 1972 \\
\hline $\mathrm{B}(1,8)$ & WNE(UW) & 0,11 & 1674 \\
\hline \multirow{24}{*}{ C $(86,1)$} & WNS(USK) & 0,14 & 459 \\
\hline & WPiA(USK) & 0,07 & 153 \\
\hline & WEiNoE(USK) & 0,17 & 327 \\
\hline & WZ(PW) & 0,02 & 188 \\
\hline & WPiA(UJ) & 0,10 & 156 \\
\hline & WDziNP(UW) & 0,08 & 180 \\
\hline & WSE(UAMP) & 0,05 & 77 \\
\hline & WOiZ(PSG) & 0,15 & 201 \\
\hline & WNE(SGGW) & 0,07 & 90 \\
\hline & WZ(UW) & 0,03 & 68 \\
\hline & $\mathrm{WP}(\mathrm{UW})$ & 0,08 & 112 \\
\hline & WSMiP(UJ) & 0,15 & 173 \\
\hline & WPiP(USK) & 0,13 & 135 \\
\hline & WEiZ(UZ) & 0,11 & 60 \\
\hline & WZ(PRz) & 0,16 & 148 \\
\hline & WZiKS(UJ) & 0,09 & 44 \\
\hline & WPiA(UWMO) & 0,02 & 38 \\
\hline & WNPiDz(UAMP) & 0,13 & 29 \\
\hline & WAiNS(PW) & 0,09 & 40 \\
\hline & WPPS(UZ) & 0,14 & 30 \\
\hline & WNE(UWMO) & 0,03 & 11 \\
\hline & WNS(SGGW) & 0,06 & 12 \\
\hline & WNS(UWMO) & 0,04 & 8 \\
\hline & WRiT(USK) & 0,13 & 0 \\
\hline $\mathrm{D}(1,2)$ & $\mathrm{WZ}(\mathrm{PL})$ & 0,21 & 662 \\
\hline \multirow{4}{*}{ E (11) } & WSNSiR(UW) & 0,22 & 334 \\
\hline & WNS(UAMP) & 0,24 & 404 \\
\hline & WPiA(UW) & 0,21 & 147 \\
\hline & WPiA(UAMP) & 0,22 & 285 \\
\hline $\mathrm{F}(4,4)$ & WZ (PCz) & 0,32 & 26 \\
\hline
\end{tabular}


* WPsycho(UW) - Wydział Psychologii Uniwersytetu Warszawskiego, WNE(UW) - Wydział Nauk Ekonomicznych Uniwersytetu Warszawskiego, WNS(USK) - Wydział Nauk Społecznych Uniwersytetu Śląskiego w Katowicach, WPiA(USK) - Wydział Prawa i Administracji Uniwersytetu Śląskiego w Katowicach, WEiNoE(USK) - Wydział Etnologii i Nauk o Edukacji Uniwersytetu Śląskiego w Katowicach, WZ(PW) - Wydział Zarządzania Politechniki Warszawskiej, WPiA(UJK) - Wydział Prawa i Administracji Uniwersytetu Jagiellońskiego, WDziNP(UW) - Wydział Dziennikarstwa i Nauk Politycznych Uniwersytetu Warszawskiego, WSE(UAMP) - Wydział Studiów Edukacyjnch Uniwersytetu im. Adama Mickiewicza w Poznaniu, WOiZ(PSG) - Wydział Organizacji i Zarządzania Politechniki Śląskiej w Gliwicach, WNE(SGGW) - Wydział Nauk Ekonomicznych Szkoły Głównej Gospodarstwa Wiejskiego w Warszawie, WZ(UW) - Wydział Zarządzania Uniwersytetu Warszawskiego, WP(UW) - Wydział Pedagogiczny Uniwersytetu Warszwskiego, WSMiP(UJK) - Wydział Stosunków Międzynarodowych i Politycznych Uniwersytetu Jagiellońskiego, WPiP(USK) - Wydział Pedagogiki i Psychologii Uniwersytetu Śląskiego w Katowicach, WEiZ(UZ) - Wydział Ekonomii i Zarządzania Uniwersytetu Zielonogórskiego, WZ(PRz) - Wydział Zarządzania Politechniki Rzeszowskiej, WZiKS(UJ) - Wydział Zarządzania i Komunikacji Społecznej Uniwersytetu Jagiellońskiego, WPiA(UWMO) - Wydział Prawa i Administracji Uniwersytetu Warmińsko-Mazurskiego w Olsztynie, WNPiDz(UAMP) - Wydział Nauk Politycznych i Dziennikarstwa Uniwersytetu im. Adama Mickiewicza w Poznaniu, WAiNS(PW) - Wydział Administracji i Nauk Społecznych Politechniki Warszawskiej, WPPS(UZ) - Wydział Pedagogiki, Psychologii i Socjologii Uniwersytetu Zielonogórskiego, WNE(UWMO) - Wydział Nauk Ekonomicznych Uniwersytetu Warmińsko-Mazurskiego w Olsztynie, WNS(SGGW) - Wydział Nauk Społecznych Szkoły Głównej Gospodarstwa Wiejskiego w Warszawie, WNS(UWMO) - Wydział Nauk Społecznych Uniwersytetu Warmińsko-Mazurskiego w Olsztynie, WRiT(USK) - Wydział Radia i Telewizji im. Krzysztofa Kieślowskiego Uniwersytetu Śląskiego w Katowicach, WZ(PL) - Wydział Zarządzania Politechniki Lubelskiej, WSNSiR(UW) Wydział Stosowanych Nauk Społecznych i Resocjalizacji Uniwersytetu Warszawskiego, WNS(UAMP) - Wydział Nauk Społecznych Uniwersytetu im. Adama Mickiewicza w Poznaniu, WPiA(UW) Wydział Prawa i Administracji Uniwersytetu Warszawskiego, WPiA(UAMP) - Wydział Prawa i Administracji Uniwersytetu im. Adama Mickiewicza w Poznaniu, WZ(PCz) - Wydział Zarządzania Politechniki Częstochowskiej.

Źródło: opracowanie własne.

Ze względu na fakt, iż niewielkiej liczebności grup poza grupa C, oraz z powodu wrażliwości testu chi kwadrat $\left(\chi^{2}\right)$ na puste pola w tabeli krzyżowej, autorzy postanowili przeprowadzić uproszczoną analizę $\mathrm{w}$ rozbiciu na dwie zasadnicze kategorie wydziałów:

- Kategoria I: wydziały „tradycyjne” (grupa strategiczna C) - w ujęciu teorii zarządzania strategicznego można byłoby je określić jako „tkwiące pośrodku” albo „wydziały, które ugrzęzły” (stuck-in-the-middle) tj. wydziały, które nie dokonały wyrazistych wyborów strategicznych [por. Porter 1998, s. 56-59];

- Kategoria II: wydziały z mniej lub bardziej ,wyrazistą strategia”" (grupy strategiczne A, B, D, E, F) - czyli grupy wydziałów wyróżniających się, albo pod względem „teoretycznej”, albo „praktycznej” działalności naukowej. 
RYSUNEK 3.

\section{Mapa grup strategicznych wydziałów reprezentujących nauki społeczne}

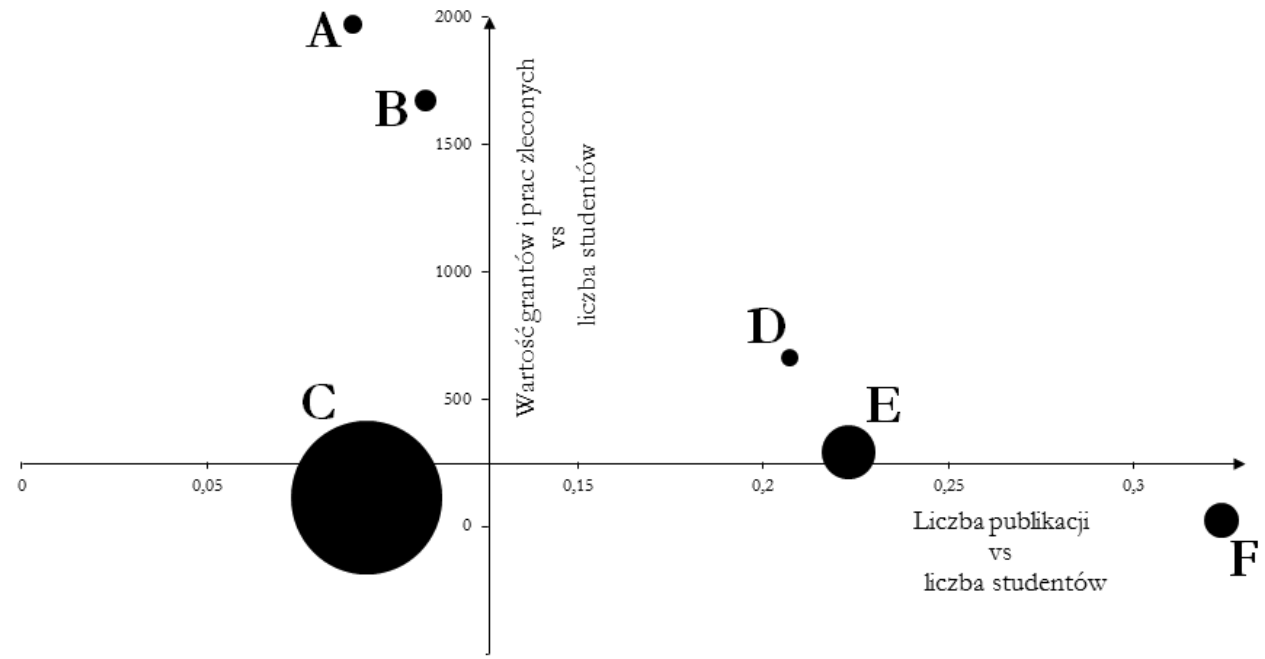

Źródło: opracowanie własne.

Przy użyciu testu chi kwadrat $\left(\chi^{2}\right)$ zweryfikowano hipotezę zerową $\left(\mathrm{H}_{0}\right.$ : nie istnieje związek między kategorią strategiczną a kategorią efektywnościową wydziałów reprezentujących nauki społeczne). Ze względu, iż wartość obliczona $\chi^{2}$ była większa od teoretycznej, można stwierdzić, że - na poziomie istotności $\alpha=0,05-$ występuje korelacja między kategorią efektywnościową wydziałów (ocenioną na podstawie wskaźnika DEA), a ich kategorią strategiczną. Przy czym, wyrazistość strategiczna sprzyja osiaganiu wysokiej efektywności (63\% wydziałów) w stosunku do wydziałów bez wyrazistej strategii (25\% wydziałów). Co ciekawe, w grupie wyróżniających się strategicznie wydziałów, więcej z nich uzyskuje niską niż średnią efektywność, zaś w grupie wydziałów bez wyrazistej strategii - więcej jest średnioefektywnych niż niskoefektywnych obiektów. Wyniki te wydają się spójne z koncepcją określaną jako paradoks strategii. Według Raynora te same zachowania i cechy strategiczne, które przyczyniają się do sukcesu strategii wiążą się również z ryzykiem porażki [2008, s. 20]. Paradoks strategii wynika z dwóch przesłanek. Po pierwsze, trwałe wybory strategiczne (czyli istota „wyrazistości strategicznej”) nie poddaja się dostosowaniom, gdy przewidywania odnośnie przyszłości okażą się nietrafne. Po drugie, z góry trafność przewidywań jest zawsze niegodna zaufania (ze względu na ich zawodność oraz nieweryfikowalność), [Raynor 2008, s. 24]. A zatem wyrazista strategia prowadzi do bardzo dobrych lub słabych wyników. Strategia „tkwienia pośrodku” prowadzi do średnich wyników. 
TABELA 2.

Tablica krzyżowa (efektywność/profil strategiczny)

\begin{tabular}{|l|c|c|c|c|}
\hline \multicolumn{1}{|c|}{$\begin{array}{c}\text { Grupa } \\
\text { strategiczna }\end{array}$} & $\begin{array}{c}\text { Wysoko- } \\
\text { efektywne }\end{array}$ & $\begin{array}{c}\text { Średnio- } \\
\text { efektywne }\end{array}$ & $\begin{array}{c}\text { Nisko- } \\
\text { efektywne }\end{array}$ & Razem \\
\hline $\begin{array}{l}\text { A, B, D, E, F } \\
\text { (,,wyróżniający się) }\end{array}$ & 5 & 1 & 2 & $\mathbf{8}$ \\
\hline $\begin{array}{l}\text { C } \\
\text { (,tradycyjni”) }\end{array}$ & 6 & 10 & 8 & $\mathbf{2 4}$ \\
\hline Razem & $\mathbf{1 1}$ & $\mathbf{1 1}$ & $\mathbf{1 0}$ & $\mathbf{3 2}$ \\
\hline
\end{tabular}

Źródło: opracowanie własne.

\section{Podsumowanie}

W artykule przedyskutowano zasadność stosowania mapy grup strategicznych narzędzia zaczerpniętego $\mathrm{z}$ teorii i praktyki sektora biznesu w sektorze publicznego szkolnictwa wyższego. Następnie koncepcję grup strategicznych zweryfikowano empirycznie opierając się na danych z 33 wydziałów reprezentujących nauki społeczne. Zgodnie $z$ przewidywaniami teorii - badania potwierdziły związek między strategicznym profilem wydziałów a ich efektywnością Najogólniej można stwierdzić, że grupy wydziałów specjalizujące się w określonej działalności tj. dokonujące trwałych, wyrazistych wyborów strategicznych (wydziały z grup strategicznych A, B, D, E, F) odznaczają się wyższą efektywnością (mierzoną za pomocą metody DEA). Wydziały z grupy strategicznej C, czyli takie, które nie podjęły trwałych, wyrazistych wyborów strategicznych osiagają niższą efektywność, przy czym najczęściej były one sklasyfikowane jako średnioefektywne (łącznie 75\%). Pomimo, iż w grupach wyrazistych strategicznie $2 / 3$ obiektów stanowiły wydziały wysokoefektywne, to jednak było w nich również więcej obiektów nisko- niż średnioefektywnych. Reasumując - ustalenia empiryczne nie tylko potwierdzają przewidywania teoretyczne odnośnie grup strategicznych, ale również wpisują się w koncepcję paradoksu strategii Raynora [2008]. W tym kontekście wydaje się, że mapa grup strategicznych jest narzędziem o dużym potencjale zastosowania w publicznym szkolnictwie wyższym.

Oczywiście należy pamiętać o ograniczeniach przeprowadzonych badań. Najważniejsze $z$ nich to, zdaniem autorów, nieliczna (około $1 / 5$ ogółu wydziałów nauk społecznych) próba badawcza, która została skompletowana metodą doboru dogodnego (kryterium: dostępności danych) - a zatem nie daje podstaw do uznania jej za reprezentatywna. Trzeba także pamiętać o dyskusyjności założeń przyjętych przez autorów. W artykule autorzy wykorzystali podejście Warning, zgodnie z którym szkoły wyższe dążą do strategicznego kompromisu między działalnością dydaktyczną a naukowa. Można dyskutować, czy jest to najważniejszy aspekt różnicujący strategie wydziałów. 
Dobór efektów (liczba studentów, liczba publikacji, wartość grantów i prac zleconych) i nakładów (liczba nauczycieli akademickich) do pomiaru efektywności może być uznany za kontrowersyjny. Takie podejście było koniecznością wynikająca z braku dostępu do szerszej puli danych, a zwłaszcza do mikrodanych dotyczących aspektów jakościowych w poszczególnych obszarach działalności wydziałów a poza tym zastosowane zmienne diagnostyczne były powszechnie stosowane zarówno w krajowych jak i zagranicznych badaniach z zakresu pomiaru efektywności instytucji szkolnictwa wyższego. Jednakże nie sposób nie zauważyć w tym miejscu sprzeczności między efektywnością - rozumianą przez autorów i wielu innych autorów z tego obszaru - jako (m.in.) relacja liczby studentów do liczebności kadry naukowo-dydaktycznej, a tzw. jakością kształcenia identyfikowaną przez MNiSW ze wskaźnikiem dostępności nauczycieli akademickich, który jest de facto odwrotnościa tej relacji. W świetle nowych zasad przyznawania dotacji, wiele jednostek uznawanych za efektywne $\mathrm{w}$ procesie kształcenie znajduje się $\mathrm{w}$ trudnej sytuacji zmuszającej je do redukcji efektywności, która w rozumieniu MNiSW staje się antytezą, ,jakości”.

Kolejna grupę ograniczeń stanowią atrybuty metody DEA tj. duża wrażliwość wyników na błędne lub nietypowe dane w obiektach uznanych za efektywne, względny charakter efektywności obiektu (co ma znaczenie ze względu na sposób doboru próby), wrażliwość na liczbę uwzględnionych nakładów i efektów.

Konkludując, przydatność stosowania metod zarządzania strategicznego (w tym również mapy grup strategicznych) w sektorze publicznym jest niezwykle obszernym i złożonym zagadnieniem badawczym. Niniejsze opracowanie w żadnej mierze nie wyczerpuje tej problematyki, a ze względu na wymienione ograniczenia powinno być raczej traktowane jako badanie pilotażowe. Zdaniem autorów, przeprowadzone w artykule rozważania - zarówno w warstwie teoretycznej, jak i empirycznej - moga stanowić inspirację do dalszych prac z tego zakresu.

\section{Literatura}

Adam A. K., 2016, Strategy and Success Factors of Business Schools, Springer Gabler, Wiesbaden.

Baran J., Pietrzak M., Pietrzak P., 2015, Efektuyyność funkcjonowania publicznych sұkót wy:ssych, „Optimum. Studia Ekonomiczne”, nr 76.

Berbeka J., 2006, Poz̧iom syycia ludności a wrrost gospodarcsy w krajach Unii Europejskiej, Wydawictwo Akademii Ekonomicznej w Krakowie, Kraków.

Carlton D., Perloff J. M., 2005, Modern Industrial Organization, Pearson Addison Wesley.

Cooper W. W., Seiford L. M., Tone K., 2007, Data Envelopment Analysis: A Comprehensive Text with Models, Applications, References and DEA-Solver Software, Kluwer Academic Publishers, Boston.

Ćwiąkała-Małys A., Nowak W., 2009, Sposoby klasyfikacji modeli DEA, „Badania Operacyjne i Decyzje", nr 3. 
De Witt B., Meyer R., 2007, Syntęa strategii, PWE, Warszawa.

Foss N. J., 1966, Research in Strategy, Economics and Michael Porter, „Journal of Management Studies", nr 33.

Fudaliński J., 2005, Analiza grup strategicznych jako element ksztattujacy proces formutowania strategii konkurencii, „Zeszyty Naukowe/Akademia Ekonomiczna w Krakowie”, nr 673.

Ghemawat P., 1999, Strategy and the Business Landscape: Text and Cases, Reading, MA, Addison-Wesley.

Gorynia M., Jaworska B., Owczarzak R., 2005, Zarz̨qdzanie strategiczne jako próba synteay teorii przedsiebiorstwa, „Ekonomista”, nr 5.

Hood Ch., 1991, A Public Management for All Seasons?, "Public Administration”, nr 69.

Kostera M., 2013, Przedmowa, [w:] Zarzadzanie uczelniq. Koncepcje i wspótczesne wyzwania, K. Leja (red.), Oficyna Wolters Kluwer, Warszawa.

Leja K., 2013, Zarzadzanie uczelniq. Koncepcje i wspótczesne wyzwania, Oficyna Wolters Kluwer, Warszawa.

Martinez M., Wolverton M., 2009, Innovative Strategy Making in Higher Education, Information Age Publishing Charlotte, NC.

Matusiak K., 2010, Budowa powiqzań nanki z biænesem w gospodarce opartej na wiedzy: Rola i miejsce uniwersytetu w procesach innowacyjnych, Oficyna Wydawnicza SGH, Warszawa.

Matyjas Z., 2011, Ekonomika organizacji przemystowej w zarzadzaniu strategicznym, „Acta Universitatis Lodziensis. Folia Oeconomia", nr 261.

McGahan A. M., Porter M. E., 1997, How Much Does Industry Matter, Really?, "Strategic Management Journal", nr 18.

McGee J., Thomas H., 1986, Strategic Groups: Theory, Research and Taxonomy, "Strategic Management Journal", nr 7.

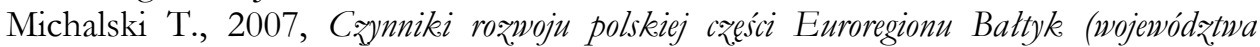
pomorskie i warmińsko-mazurskie, [w:] Uwarunkowania rozwoju rosyjskiej i polskiej cæeśsi Euroregionu „Battyk”, (red.) G.M. Fiedorowa, Wyd. „Bernardinum” Sp. z o.o., Gdynia-Pelpin.

Musgrave R. A., 1987, Merit Goods, [w:] The New Palgrave: A Dictionary of Economics, J. Eatwell, J. Milgate, P. Newman (red.), Londyn.

Newman H. H., 1978, Strategic Groups and the Structure-Performance Relationship, "The Review of Economics and Statistics", nr 60.

O'Flynn J., 2007, From New Public Management to Public Value: Paradigmatic Change and Managerial Implications, "The Australian Journal of Public Administration”, nr 66.

Paliszkiewicz J., 2010, Scenariusze i strategie rozwoju szkolnictwa nyższego w Polsce $i$ za granica Analiza foresightón $i$ dokumentón strategicznych. Raport ₹ badania, tryb dostępu: [http://akademickiemazowsze2030.pl /Data/File/26.pdf, data wejścia: 30.04. 2017].

Parker L. D., 2012, From Privatised to Hybrid Corporatised Higher Education: A Global Financial Management Discourse, "Financial Accountability \& Management", nr 28.

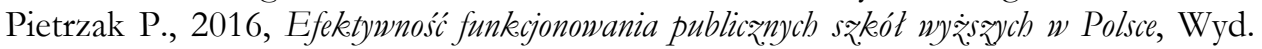
SGGW, Warszawa. 
Pietrzak M., Pietrzak P., 2017, Mapping strategic groups in higher education: Evidence on the Polish technical faculties, "Online Journal of Applied Knowledge Management", nr 5(2), tryb dostępu: [http://www.iiakm.org/ojakm/articles/2017/volume5_2/ OJAKM_Volume5_2pp1-15.pdf, data wejścia: 17.05.2017].

Porter M. E., 1981, The Contributions of Industrial Organization to Strategic Management, "Academy of Management Review", nr 6.

Porter M. E., 1998, Strategia konkurencii. Metody analizy sektorów i konkurentów, PWE, Warszawa.

Pruett M., Thomas H., 1994, Introduction, [in:] Strategic Groups, Strategic Moves and Performance, H. Daems, H. Thomas (eds), Pergamon Press, Great Yarmouth.

Raynor M. E., 2008, Paradoks strategii, Wyd. Studio Emka, Warszawa.

Rumelt R. P., 1991, How Much Does Industry Matter?, "Strategic Management Journal”, nr 12.

Rumelt R. P., Schendel D., Teece D. J., 1991, Stratgic Management and Economics, "Strategic Management Journal", nr 12.

Schendel D., Hatten K. J., 1972, Business Policy or Strategic Management: A Broader View for an Emerging Discipline, "Academy of Management Proceedings", nr 371.

Scherer F. M., 1970, Industrial Market Structure and Economic Performance, RAND McNALLY College Publishing Company, Chicago.

Schimank U., 2005, 'New Public Management' and the Academic Profession: Reflections on the German Situation, "Minerva", nr 43.

Schmalensee R., 1985, Do Markets Differ Much?, "The American Economic Review”, nr 75.

Sprawozdanie Rektora SGGW prof. dr. hab. Alojzego Szymańskiego z działalności uczelni za rok 2013/2014, Warszawa.

Sprawozdanie Rektora z działalności Politechniki Śląskiej w roku 2013/2014, Gliwice.

Sprawozdanie Rektora z działalności Politechniki Warszawskiej w okresie: 1.09.2013 -31.08.2014, Warszawa.

Sprawozdanie z działalności Politechniki Rzeszowskiej w 2013 roku, Rzeszów.

Sprawozdanie roczne Rektora z dzialalności Uniwersytetu im. Adama Mickiewicza w Poznaniu za rok 2013/2014, Poznań.

Sprawozdanie roczne Rektora Uniwersytetu Jagiellońskiego za rok 2013/2014, Kraków.

Sprawozdanie z działalności uczelni w roku akademickim 2013/2014, Olsztyn.

Sprawozdanie Rektor Uniwersytetu Warszawskiego z działalności uczelni w 2013 roku, Warszawa.

Sprawozdanie z działalności w roku akademickim 2013/2014, Zielona Góra.

Sprawozdanie z działalności Politechniki Lubelskiej za rok akademicki 2013/2014 2014, Lublin.

Sprawozdanie z działalności naukowo-badawczej Uczelni w roku 2013/2014, Częstochowa.

Sprawozdanie Rektora z działalności Uniwersytetu Śląskiego w Katowicach, 2014, Katowice. 
Sułkowski L., 2016, Kultura akademicka. Koniec utopii?, PWN, Warszawa.

Sztompka P., 2016, Uniwersytet w przestrzeni spolecznej, „Zarządzanie Publiczne”, nr 36.

Tahar S., 2013, Resource Allocation in Higher Education in the Context of New Public Management, "Public Management Review", nr 15.

Thompson A. A., Strickland A. J., 1990, Strategic Management: Concepts and Cases, Richard D. Irwin. Homewood, IL.

Tirole J., 1988, The Theory of Industrial Organization, The MIT Press, Cambridge MA.

Warning S., 2004, Performance Differences in German Higher Education: Empirical Analysis of Strategic Groups, "Review of Industrial Organization", nr 24.

Wilkesman U., Schmid Ch. J., 2012, The Impacts of New Governance on Teaching at Germany Universities. Findings from a National Survey, "Higher Education", nr 63.

Wójcik-Augustyniak M., 2011, Analysis of the strategic groups maps of the bigher schools sector in Poland, "Zeszyty Naukowe Uniwersytetu Przyrodniczo-Humanistycznego w Siedlcach. Seria: Administracja i Zarządzanie", nr 91.

Zawicki M., 2011, Nowe zarzadzanie publične, PWE, Warszawa. 